\title{
Analysis of phytochemicals, minerals and in vitro antioxidant activities of Gongronema latifolium leaves
}

\author{
Usunobun Usunomena and Igwe V. Chinwe \\ Department of Biochemistry, Faculty of Science, Edo University, Iyamho, Edo State, Nigeria
}

\section{ABSTRACT}

Background study: Gongronema latifolium is primarily used as spice and vegetable as well as a herb in traditional medicine in the treatment of malaria, diabetes and hypertension. This study is aimed at providing in vitro laboratory knowledge on Gongronema latifolium leaves.

Methods: Minerals were analyzed using Atomic Absorption Spectrophotometer while phyto-nutrients were screened using standard laboratory procedures. 2,2-diphenyl-1-picrylhydrazyl (DPPH)-radical scavenging and reducing power activities were determined spectrophotometrically.

Results: Results showed that Gongronema latifolium leaves contains flavonoids, tannins, saponins, alkaloids, terpenoids etc as well as minerals such as calcium (333.40mg/100g), magnesium $(38.90 \mathrm{mg} / 100 \mathrm{~g})$, potassium $(83.69 \mathrm{mg} / 100 \mathrm{~g})$, sodium $(31.02 \mathrm{mg} / 100 \mathrm{~g})$, phosphate $(51.13 \mathrm{mg} / 100 \mathrm{~g})$, iron $(4.88 \mathrm{mg} / 100 \mathrm{~g})$, zinc $(2.19 \mathrm{mg} / 100 \mathrm{~g})$ and chromium $(0.98 \mathrm{mg} / 100 \mathrm{~g})$. DPPH-radical scavenging and reducing power activities of Gongronema latifolium leaves showed the plant be concentration dependent as free radical scavenging activity increases as concentration increases from $0.2-1.0 \mathrm{mg} / \mathrm{ml}$.

Conclusion: The presence of bioactive agents, minerals and free radical scavenging potentials of Gongronema latifolium leaves makes it a beneficial medicinal plant.

Keywords:

2,2-diphenyl-1-picrylhydrazyl, Gongronema latifolium, minerals, phytochemicals, reducing power

\section{INTRODUCTION}

Gongronema latifolium of the family Asclepiadaceae, locally known as arokeke by the Yoruba and utazi by the Igbos is a tropical rainforest plant primarily used as spice and vegetable in the traditional folk practice [1]. Traditionally, the southern part of Nigeria uses this herb in the treatment of malaria, diabetes and hypertension as well as a laxative. A maceration of the leaves in alcohol is taken to treat bilh.arzia, viral hepatitis and as a general antimicrobial agent [2]. It is also taken as a tonic to treat loss of appetite [3]. Asthma patients chew fresh leaves to relieve wheezing [4] and a decoction of the roots, combined with other plant species, is taken to treat sickle cell anaemia. Nwanjo [5] reported the anti lipid peroxidative activity of the plant. The objective of this study is to provide in vitro information of the leaves of Gongronema latifolium and to create awareness of the health benefits.

\section{MATERIALS AND METHODS}

\section{Collection, Identification and Preparation of Plant materials}

The fresh leaves Gongronema latifolium were collected from a local farm in south eastern part of Nigeria. Identification and authentication were carried out after which the leaves were washed and air dried at room temperature for fourteen (14) days. They were grounded into fine powder using an electric blender and stored in a cool dry container until use for analysis.

\section{Phytochemical analysis}

Qualitative phytochemical screening using standard methods as described [6-10] were carried out. 


\section{Mineral analysis}

Mineral analysis was carried out using Atomic Absorption Spectrophotometer (AAS) as previously done by Usunobun and Okolie [11-12].

\section{Determination of reducing power ability}

The reducing power activity of Gongronema latifolium leaves was carried out using the reducing power method as described by Aiyegoro and Okoh [13]. A mixture containing $2.5 \mathrm{ml}$ of $0.2 \mathrm{M}$ phosphate buffer ( $\mathrm{pH}$ 6.6) and $2.5 \mathrm{ml}$ of $\mathrm{K}_{3} \mathrm{Fe}(\mathrm{CN})_{6}(1 \% \mathrm{w} / \mathrm{v})$ was added to $1.0 \mathrm{ml}$ of stock Gongronema latifolium leaves filtrate $(0.2-1.0 \mathrm{mg} / \mathrm{ml})$ prepared in distilled water. The resulting mixture was incubated for $20 \mathrm{~min}$ at $50^{\circ} \mathrm{C}$, followed by the addition of $2.5 \mathrm{ml}$ of TCA $(10 \% \mathrm{w} / \mathrm{v})$, followed by centrifugation at $3000 \mathrm{rpm}$ for $10 \mathrm{~min} .2 .5 \mathrm{ml}$ of the supernatant was mixed with $2.5 \mathrm{ml}$ of distilled water and $0.5 \mathrm{ml}$ of $\mathrm{FeCl}_{3}(0.1 \%$ $\mathrm{w} / \mathrm{v})$. The absorbance was measured at $700 \mathrm{~nm}$ against reagent blank sample. Increased absorbance of the reaction mixture indicates higher reducing power of Gongronema latifolium leaves.

\section{2,2-diphenyl-1-picrylhydrazyl (DPPH) radical scavenging ability}

The DPPH method according to Liyana-Pathiana and Shahidi [14] was used for the determination of DPPH free radical scavenging activity of the Gongronema latifolium leaves as follows: DPPH $(1 \mathrm{ml}, 0.135 \mathrm{mM})$ prepared in methanol was mixed with $1.0 \mathrm{ml}$ of stock Gongronema latifolium leaves filtrate ranging in concentration from 0.2 to $1.0 \mathrm{mg} / \mathrm{ml}$. The reaction mixture was then vortexed thoroughly and left in the dark at room temperature for $30 \mathrm{~min}$. The absorbance was measured at $517 \mathrm{~nm}$. The scavenging ability was calculated using the equation: DPPH scavenging activity $\left.(\%)=\left[\left(\mathrm{Abs}_{\text {control }}-\mathrm{Abs}_{\text {sample }}\right)\right] /\left(\mathrm{Abs}_{\text {control }}\right)\right] \times$ 100 ,

Where: $\mathrm{Abs}_{\text {control }}$ is the absorbance of DPPH + methanol and $\mathrm{Abs}_{\text {sample }}$ is the absorbance of DPPH radical + sample (sample or standard).

\section{Statistical analysis}

Data obtained from this study were expressed as mean value \pm standard deviation.

\section{RESULTS}

Phytochemical screening of Gongronema latifolium leaves in this study showed that they contain secondary metabolites like alkaloids, flavonoids, tannins, saponins etc as presented in (Tables 1).

\section{Table 1: Phytochemical screening of Gongronema latifolium leaves}

\begin{tabular}{|l|l|}
\hline Phytochemicals & $\begin{array}{l}\text { Gongronema } \\
\text { latifolium } \text { leaves }\end{array}$ \\
\hline Flavonoids & Positive \\
\hline Saponins & Positive \\
\hline Alkaloids & Positive \\
\hline Tannins & Positive \\
\hline Terpenoids & Positive \\
\hline Steroids & Positive \\
\hline Reducing sugars & Negative \\
\hline
\end{tabular}

The result of mineral analysis shown in table 2 reveals Gongronema latifolium leaves to be higher in calcium $(333.40 \mathrm{mg} / 100 \mathrm{~g})$ and least in chromium $(0.25 \mathrm{mg} / 100 \mathrm{~g})$. Other minerals present includes magnesium $\quad(38.90 \mathrm{mg} / 100 \mathrm{~g}), \quad$ potassium $(83.69 \mathrm{mg} / 100 \mathrm{~g})$, sodium $(31.02 \mathrm{mg} / 100 \mathrm{~g})$, phosphate $(51.13 \mathrm{mg} / 100 \mathrm{~g})$, iron $\quad(4.88 \mathrm{mg} / 100 \mathrm{~g})$, zinc $(2.19 \mathrm{mg} / 100 \mathrm{~g})$ and chromium $(0.98 \mathrm{mg} / 100 \mathrm{~g})$.

Table 2: Mineral composition of Gongronema latifolium leaves $(\mathrm{mg} / \mathbf{1 0 0 g})$

\begin{tabular}{|l|l|}
\hline Minerals & $\begin{array}{l}\text { Gongronema latifolium } \\
\text { leaves }(\mathrm{mg} / 100 \mathrm{~g})\end{array}$ \\
\hline Calcium & $333.40 \pm 2.01$ \\
\hline Magnesium & $38.90 \pm 1.22$ \\
\hline Potassium & $83.69 \pm 1.30$ \\
\hline Sodium & $31.02 \pm 1.08$ \\
\hline Phosphate & $51.13 \pm 1.17$ \\
\hline Iron & $4.88 \pm 0.46$ \\
\hline Zinc & $2.19 \pm 0.09$ \\
\hline Copper & $0.98 \pm 0.04$ \\
\hline Chromium & $0.25 \pm 0.02$ \\
\hline
\end{tabular}

Values are means \pm SD for 2 determinations 
The scavenging activities of DPPH radical and reducing power ability exerted by Gongronema latifolium leaves is shown in Fig.1 and 2. The scavenging effect of plant leaf in the range of 0.2$1.0 \mathrm{mg} / \mathrm{ml}$ increased in a concentration-dependent manner.

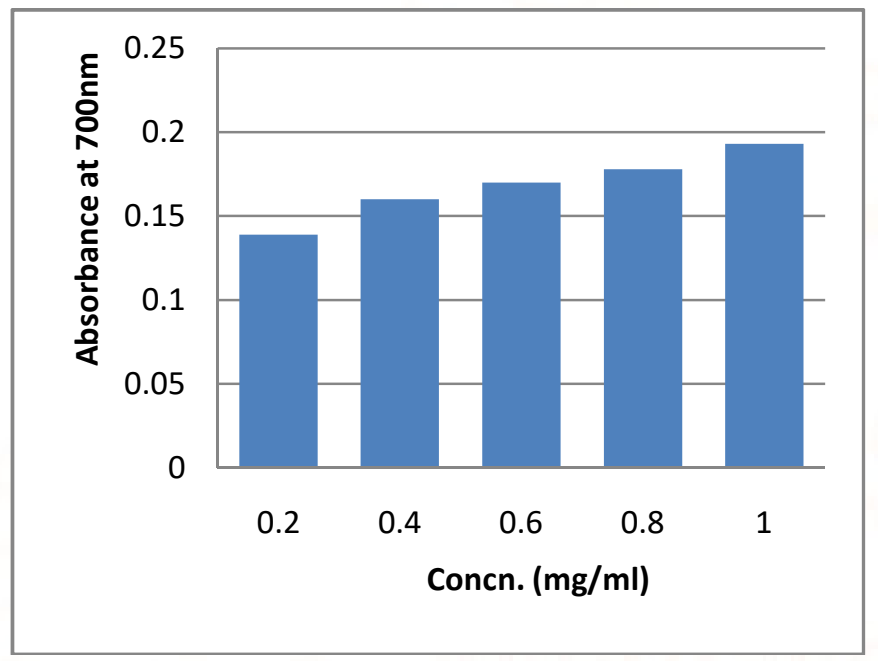

Figure 1: Reducing power ability of Gongronema latifolium leaves

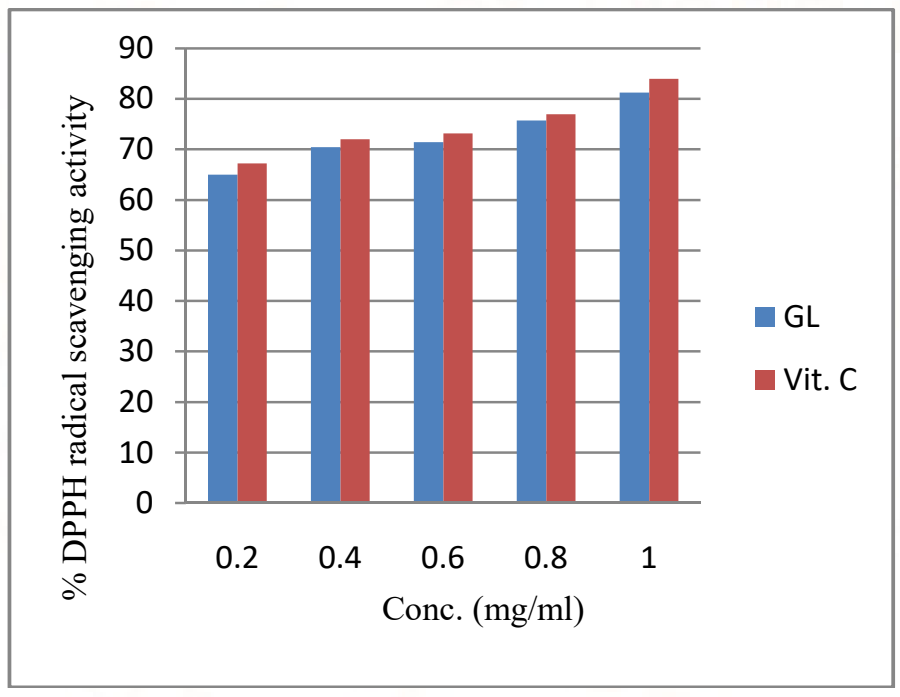

Figure 2: DPPH radical scavenging activity of Gongronema latifolium (GL) leaves

\section{DISCUSSION}

The presence of phyto-nutrients such as flavonoids, saponins, alkaloids and tannins in Gongronema latifolium leaves is an indication that the plant possesses the ability to scavenge for free radicals, thus health promoting in action ${ }^{15}$. The phytochemicals present in this study is similar to previously published phytochemicals in other plant leaves [16-19].
Calcium content of Gongronema latifolium (333.40mg/100g) is high compared to $295 \mathrm{mg} / 100 \mathrm{~g}$ of Celosia argentea [20], $1118.30 \mathrm{mg} / 100 \mathrm{~g}$ of Annona muricata and $1264.18 \mathrm{mg} / 100 \mathrm{~g}$ of Vernonia amygdalina [11-12]. Calcium, an important intracellular messenger, and cofactor for enzymes [21] plays roles in release of neurotransmitters and signaling. Zinc content of Gongronema latifolium $(2.19 \mathrm{mg} / 100 \mathrm{~g})$ is low compared to $5.42 \mathrm{mg} / 100 \mathrm{~g}$ of Celosia argentea [20] but high compared to $0.83 \mathrm{mg} / 100 \mathrm{~g}$ of Annona muricata and $1.42 \mathrm{mg} / 100 \mathrm{~g}$ of Vernonia amygdalina [11-12]. Sodium content of Gongronema latifolium $(31.02 \mathrm{mg} / 100 \mathrm{mg}$ ) is low compared to $48.31 \mathrm{mg} / 100 \mathrm{~g}$ of Vernonia amygdalina, $69.49 \mathrm{mg} / 100 \mathrm{~g}$ of Annona muricata [11-12] and $71.32 \mathrm{mg} / 100 \mathrm{~g}$ of Celosia argentea [20]. Potassium content of Gongronema latifolium $(83.69 \mathrm{mg} / 100 \mathrm{~g})$ is low compared to $128.33 \mathrm{mg} / 100 \mathrm{~g}$ of Celosia argente $^{20}$ but high when compared to $36.31 \mathrm{mg} / 100 \mathrm{~g}$ of Annona muricata and $62.79 \mathrm{mg} / 100 \mathrm{~g}$ of Vernonia amygdalina [11-12]. Copper content of Gongronema latifolium $(0.98 \mathrm{mg} / 100 \mathrm{mg})$ is low compared to $1.95 \mathrm{mg} / 100 \mathrm{~g}$ of Vernonia amygdalina and $1.42 \mathrm{mg} / 100 \mathrm{~g}$ of Annona muricata [11-12] and $2.18 \mathrm{mg} / 100 \mathrm{~g}$ of Celosia argentea [20]. Iron content of Gongronema latifolium $(4.88 \mathrm{mg} / 100 \mathrm{~g})$ is low compared to $13.90 \mathrm{mg} / 100 \mathrm{~g}$ of Annona muricata, $32.20 \mathrm{mg} / 100 \mathrm{~g}$ of Vernonia amygdalina and $35.16 \mathrm{mg} / 100 \mathrm{~g}$ of Celosia argentea [20].

The reducing power assay is often used to evaluate the ability of an antioxidant to donate an electron which is an important mechanism of phenolic antioxidant action [22]. Many reports have revealed that there is a direct correlation between antioxidant activities and reducing power of certain plant extracts [23-24]. The ability of Gongronema latifolium leaves to exhibit reducing power potential, shows its effectiveness to halt the oxidation of cellular macromolecules by oxidizing molecules that could arise from drugs or toxins metabolism.

The result of DPPH scavenging activity assay in this study indicates that Gongronema latifolium leaves is 
potently active, suggesting that the plant contain agents that are capable of donating hydrogen to a free radical in order to remove odd electron which is responsible for radical's reactivity. The concentrationdependent scavenging activity of DPPH radical by Gongronema latifolium was found to be appreciable; an implication that the plant may be useful for treating radical related pathological damage.

In conclusion, the presence of phytochemicals, minerals and free radical scavenging potentials makes Gongronema latifolium leaves a beneficial medicinal plant. The phytochemicals present such as tannin and flavonoid supports the usefulness of Gongronema latifolium in the treatment of various infections

\section{References}

1. Ugochukwu N.H, Babady N.E, Cobourne M, \& Gasset S.R (2003). The effect of Gonglonema latifolium leaf extract on serum lipid profile and oxidative stress of hepatocytes of diabetic rats. Journal of Bioscience 28: 1-5.

2. Okigbo R.N, Anuaga C.L, \& Amadi J.E. (2009). Advances in selected medicinal and aromatic plants indigenous to Africa. Journal of Medicinal Plants Research 3(2): 86-95.

3. Akpan P.A. (2004). Food from Nigeria Forest African farming September/ October. ( $1_{\text {st }}$ edn), Spectrum Books Limited, Ibadan, Nigeria.

4. Okafor J.C. (2002). Tropical plants in health care delivery in Nigeria: Contributions of some members of Compositae (Asteraceae). Journal of College of Medicine 7(2): 129-131.

5. Nwanjo H.U. (2006). Lipid profile of rats treated with Gonglonema latifolium in Albino rats". Journal of Bioscience 17: 23-27.

6. Sofowora L.A. (1993). Medicinal plants and Traditional Medicine in Africa. Spectrum Books Ltd, Ibadan, pp55-71.

7. Trease G.E. \& Evans W.C. (1985). Pharmacognosy 11th Ed., Tindall Ltd, London, pp60-75.

8. Harbone J.B. (1998). Methods of extraction and isolation. In: Phy-tochemical Methods. Chapman and Hall, London; Pp60-66.
9. Usunobun U., Okolie N.P., Anyanwu O.G., Adegbegi A.J. \& Egharevba M.E. (2015). Phytochemical screening and proximate composi-tion of Annona muricata leaves. European Journal of Botany, Plant science and Phytology 2(1): 18-28.

10. Usunobun U \& Okolie P.N. (2016). Phytochemical analysis and proximate composition of

Vernonia amygdalina. International Journal of Scientific World 4 (1): 11-14.

11. Usunobun U. \& Okolie N.P. (2015). Phytochemical analysis and mineral composition of Annona muricata leaves. International Journal of Research and Current Development 1(1): 38-42.

12. Usunobun U. \& Okolie N.P. (2015). Phytochemical, trace and mineral composition of Vernonia amygdalina leaves. International Journal of Biological and Pharmacentical Research. 6(5): 393399.

13. Aiyegoro O.A. \& Okoh A.I. (2010). Preliminary phytochemical screening and in vitro antioxidant activities of the aqueous extract of Helichrysum longifolium DC. BMC Complementary and Alternative Medicine 10: 21-32.

14. Liyana-Pathiana C.M. \& Shahidi F. (2005). Antioxidant activity of commercial soft and hard wheat (Triticum aestivium L) as affected by gastric $\mathrm{pH}$ conditions. Journal of Agricultural Food Chemistry 53: 2433-40.

15. Ferguson L.R. (2001). Role of plant polyphenols in genomic stability. Mutation Research 475: 9-111.

16. Usunobun U. \& Igwe V.C. (2016a). Phytochemical analysis, mineral composition and in vitro antioxidant activities of Solanum macrocarpon leaves. International Journal of Health 4(1): 62-65

17. Usunobun U. \& Igwe V.C. (2016b). Phytochemical screening, mineral composition and in vitro antioxidant activities of Pterocarpus mildbraedii leaves. International Journal of Scientific World 4: 23 $-26$.

18. Usunobun U. \& Ewere G.E. (2016). Phytochemical analysis, Mineral Composition and in vitro antioxidant activities of Chromolaena Odorata leaves. ARC Journal of Pharmacentical Sciences 2(2): $16-20$ 
19. Usunobun U. \& Uwadiae E. (2016). In vitro medicinal studies on Ocimum gratissimum leaves. ARC Journal of Pharmaceutical Sciences 2(2):1-5

20. Usunobun U. \& Ekpemupolo I.S. (2016).

Phytochemical analysis, mineral composition and

in vitro antioxidant activities of Celosia argentea leaves. International Journal of Scientific World 4 (1): 19-22

21. Milne DB. 2000. Laboratory assessment of trace element and mineral status. Totowa, NJ: Humana Press.

22. Mohamed H., Ons M., Yosra E.T., Rayda S., Neji G., \& Moncef N. (2009).Chemical composition and antioxidant and radical scavenging activities of Periploca laevigata root bark extracts," Journal of the Science of Food and Agriculture 89(5): 897-905.

23. Koleva I.I, Van Beek T.A., Linssen J.P.H, De Groot A. \& Evstatieva L.N.(2002). "Screening of plant extracts for antioxidant activity: a comparative study on three testing methods," Phytochemical Analysis 13(1): 8-17.

24. Benzie I.F.F \& Szeto Y.T. (1999). "Total antioxidant capacity of teas by the ferric reducing/ antioxidant power assay," Journal of Agricultural and Food Chemistry 47(2): 633-636. 